\title{
Evaluation of Anthropometric Compatibility of Office Furniture with Mobile, Desktop and Web Software Platforms and Posture Exercise Program- An Application-Based Study
}

\section{Ofıs Mobilyasının Antropometrik Uygunluğunun Mobil, Masaüstü ve Web Yazılım Platformları ile Değerlendirilmesi ve Postür Egzersiz Eğitimi-Bir Aplikasyon Çalışması}

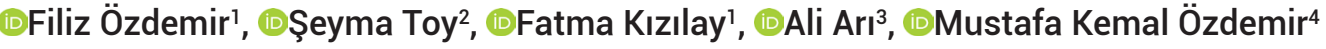 \\ IInönü University, Faculty of Health Sciences, Department of Physiotherapy and Rehabilitation, Malatya, Turkey \\ ${ }^{2}$ Karabuk University, Faculty of Medicine, Department of Anatomy, Karabük, Turkey \\ ${ }^{3}$ Inönü University, Faculty of Engineering, Department of Computer Engineering, Malatya, Turkey \\ ${ }^{4}$ Inönü University, Faculty of Science, Department of Mathematics, Malatya, Turkey \\ Copyright@Author(s) - Available online at www.dergipark.org.tr/tr/pub/medr \\ Content of this journal is licensed under a Creative Commons Attribution-NonCommercial 4.0 International License.
}

\begin{abstract}
Aim: Work-related musculoskeletal disorders (WMSDs) have been observed commonly in office workers with the development of technology. These problems affect the quality of life for individuals and also productivity in the workplace. The aim of this study is to design an application in which the anthropometric compatibility of office furniture is evaluated and individualized planned posture exercise training is included.

Material and Method: The designed application consists of 4 modules. An application has been designed to classify the compatibility and incompatibilities in the first and second modules. The third and fourth modules are designed for personalized exercise definition and follow-up.

Results: Within the scope of the application, 4 modules were combined in a single application. The modules that evaluate the anthropometric suitability of office furniture and calculate the compatibility of office furniture; it is the first and second module. The third module contains the definition of the exercise. The fourth module includes the follow-up of the exercise program.

Conclusion: It is obvious that the current designed application will provide innovation to work health. Based on our hypothesis, we think that the designed application will also be effective for health protection and promotion in office workers.
\end{abstract}

Keywords: Work-related musculoskeletal disorders; anthropometry; exercise; office workers; application

Öz

Amaç: Ofıs çalışanlarında işe bağlı kas-iskelet sistemi hastalıkları ve şikayetleri yaygın olarak görülmektedir. Bu problemler bireylerin yaşam kalitesini ve iş verimini etkilemektedir. Bu çalışmanın amacı, ofis mobilyasının antropometrik uygunluğunun değerlendirildiği ve kişiye özel planlanmış postür egzersiz eğitiminin yer aldığı mobil ve masaüstü yazılım platformları geliştirmektir.

Materyal ve Metot: Tasarlanan uygulama toplam 4 modülden oluşmaktadır. Birinci ve ikinci modüllerde uyumluluk ve uyumsuzlukları sınıflandırmak için bir uygulama tasarlandı. Üçüncü ve dördüncü modülller ise kişiye özel egzersiz tanımını ve takibinin yapılması için tasarlandı. Bulgular: Uygulama kapsamında 4 modül tek bir uygulamada birleştirildi. Ofıs mobilyasının antropometrik uygunluğunun değerlendirildiği ve ofıs mobilyasının uyumluluğunun hesaplandığı modüller; birinci ve ikinci modüldür. Üçüncü modül egzersizin tanımını içermektedir. Dördüncü modül, egzersiz programının takibini içermektedir.

Sonuç: Ofıs çalışanlarında sağlığın korunması ve geliştirilmesinde rol alması amacı ile bu uygulama geliştirildi. Geliştirilen insan odaklı bu ürünün iş ortamında ortaya çıkabilecek sağlık problemlerini azaltarak verimliliği ve yaşam kalitesini arttırabileceğini düşünmekteyiz.

Anahtar Kelimeler : İşle ilgili kas-iskelet sistemi problemleri; antropometri; egzersiz; ofıs çalışanları; aplikasyon 


\section{INTRODUCTION}

With the development of technology in the world, the use of computers in workplaces has been increasing. The advent of computers to workplaces increases employees' productivity. However, at the same time, the use of computers brings several health problems, especially in terms of work-related musculoskeletal disorders (WMSDs), causing changes to existing risk factors and the development of new ones in work organizations. WMSDs are defined as injury or disease of the muscle, nerve, tendon, joint, cartilage and spinal discs that develops as a result of exposure to risk factors in the working environment $(1,2)$.

Complaints related to the musculoskeletal system constraints on movement and inability to continue work are common among office workers in the work environment. Incompatibility between anthropometric measurement of individual and office furniture and static posture in computer use are associated with musculoskeletal disorders $(3,4)$.

\section{Anthropometric Features in Office Workers}

It is important for the workplace environment to be compatible with people's anthropometric measurements. It is known that incompatibility between the anthropometric properties of individuals and office furniture features causes problems like WMSDs. To design office workplaces well, correct anthropometric data are needed $(5,6)$.

Up to now, there have been various studies about the furniture design according to the human's anthropometric measurements. These works can be broadly divided into two categories. The first category covers the studies related to the statistical methods and the second category involves the studies related to the artificial intelligence and data mining methods (7-9).

\section{Definition of Posture in Office Workers}

The posture adopted during work tasks is defined as the work posture. The body maintains a good posture, minimizes energy expenditure, improves the functioning of organs and protects against improper positions that will damage the structures in our body during professional practice. Office workers often have to work in a static sitting position. Prolonged periods of sitting position in office workers is a risk factor for postural problems $(4,10)$. In the literature, the prevalence of WMSDs in office workers has been reported to result from poor body posture and inappropriate workstations. Therefore, it is necessary to investigate the positions of the employees at the workstations and to make some interventions $(11,12)$.

\section{Exercise Approaches in Office Workers}

The treatment of WMSDs involves alternative approaches $(13,14)$. It is well documented that exercise is used as an effective, safe and cost-effective method in workers (15). In several studies it is reported that exercise interventions are applicable component in improving health in office workers. In evidence-based intervention research, individualized exercise programs stand out. However, encouraging patients to comply with exercise training is a challenge for healthcare providers. Innovative interventions have critical role in controlling global burdens on office workers $(16,17)$.

\section{The Hypothesis}

WMSDs are common in office workers. These problems affect the quality of life for individuals and also productivity in the workplace. Our hypothesis is that the designed application will guide practitioners in the process of detecting and reducing WMSD risks. The usage of the designed application will be effective in decreasing musculoskeletal complaints, which can cause pain, limit motion and result in an inability to continue to work among office workers.

\section{MATERIAL AND METHOD}

In our hypothetical protocol it has been assessed that Evaluation of Anthropometric Compatibility of Office Furniture with Mobile, Desktop and Web Software Platforms and Posture Exercise Program- An applicationbased study. The protocol was approved based on the ethical standards of the Declaration of Helsinki. The permissions and consents required for the study were obtained from the Inonu University Health Sciences Non-Interventional Clinical Research Ethics Committee (Approval number $=2019 / 5-28$ ).

The designed application has two-phase for each individual; each phase consists of 2 modules. The application consists of a total of 4 modules. In the first and second module, an application was designed for classifying the compatibility and incompatibility of the office furniture used according to the anthropometric measurements of the individuals and determining the furniture measurement values that fit the anthropometric measurements of the individual $(18,19)$. Extreme learning machine (ELM) was used for classification and regression in application. ELM is a learning algorithm proposed by Huang et al. for a simple and effective single hidden layer feedforward neural network. In the ELM scheme, input weights in the hidden layer are randomly initialized and remain constant throughout the process, while the output weights are calculated via the least squares method (20).

\section{RESULT}

Definitions of how each type of anthropometric data and office furniture dimensions are presented in Table 1. Determined compatibility values between anthropometric data and office furniture are shown in Table 2. A computer, which has a $3.50 \mathrm{GHz}$ processor and $8 \mathrm{~GB}$ of memory, was used in experiments and MATLAB 2016 software was used in implementation of the proposed system. The 30 participant's anthropometric data were evaluated for the system design. 
Table 1. Definitions of how each type of anthropometric data and office furniture

Anthropometric Data

Measuring Technique

Height

Elbow height

Shoulder height

Knee height

Popliteal height

Hip-popliteal length

Chair's sitting surface height

Chair's sitting area depth

Desk/table height

The distance from the top of the front edge to the ground was measured.

Table 2. Determined compatibility values between anthropometric data and office furniture

Compatibility Values

Popliteal height-seat The seat surface height should be in the surface height range of $88-95 \%$ of the popliteal height

Hip-popliteal lengthsitting place depth

The sitting place depth should be in the range of $80-95 \%$ range of the hippopliteal length

Elbow and shoulder height-desk height
The third module contains the definition of posture exercises. Exercise program is determined by the selection of the exercise database in the application, the specified exercises are uploaded to the mobile, desktop or web software account of the workers. In this module, the reminder feature is also active and the user is given a warning in the specified time zones and the exercises are repeated according to these warnings within the specified daily definitions. Exercises examples from database are shown in Figure 1. The fourth module includes the follow-up of posture exercises. This module, which provides regular follow-up of posture exercises, includes the data presented in 30-day periods, where the users can see their own progresses. Daily notifications and exercise follow-ups are significant functional features of this module. These features are shown in Figure 2.

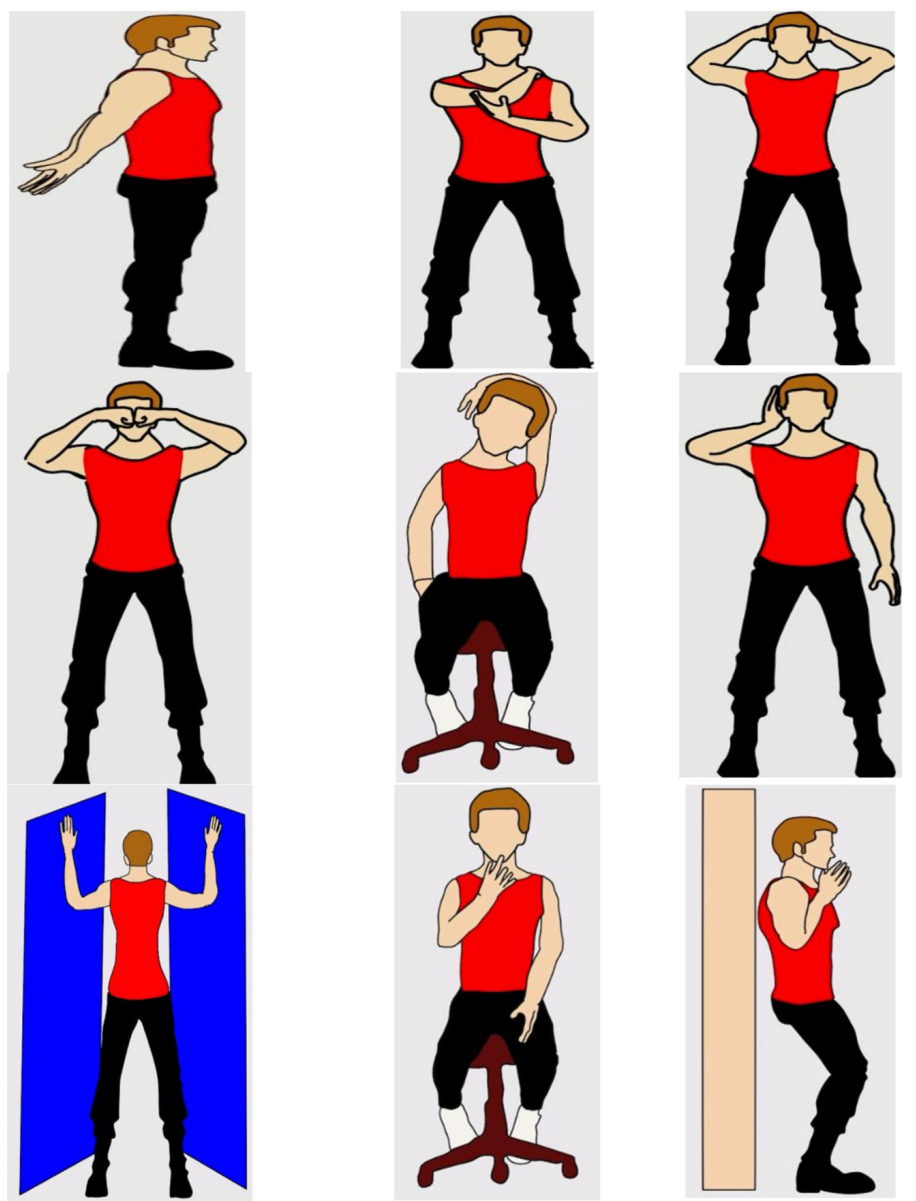

Figure 1. Examples of exercise

\section{DISCUSSION}

Considering that office workers spend most of their working time sitting on chairs at the table; using furniture compatible for individual anthropometric dimensions will minimize musculoskeletal problems. In this way, office workers will be able to work more productively at workplaces with higher quality working standards. In the existing system, there are furniture with standard dimensions, and it is not possible for these furniture 


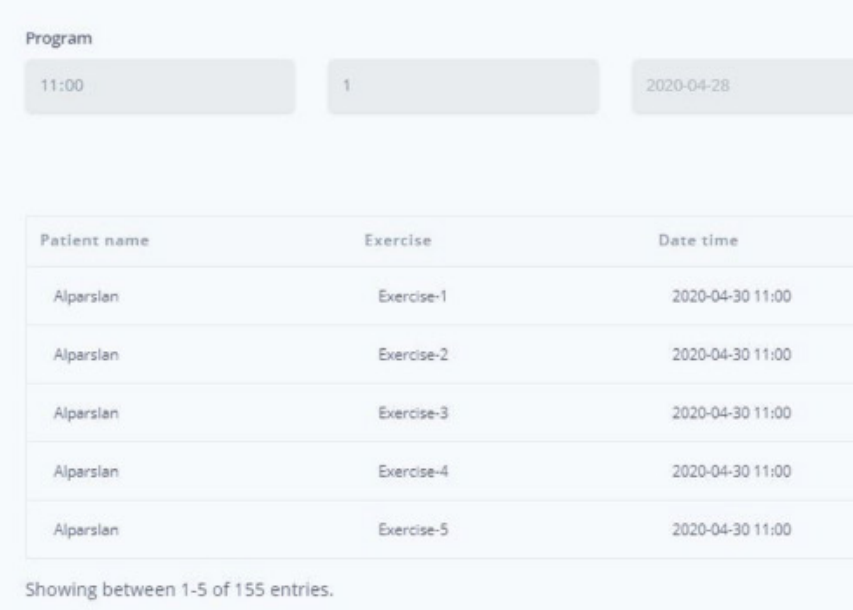

Figure 2. Tracking of Exercise

sizes to provide the same compatibility in individuals with different anthropometric features.

Another component of the hypothesis is to provide, follow and accomplish an individualized exercise program for office workers through the mobile, desktop and web software program. Other approaches that are frequently preferred in the clinic, the program consisting of standard exercises is given to the people as a brochure, and they are asked to perform the given exercises in a certain period and number of repetitions. With these methods, it is not possible to check whether the people do the exercises correctly and repeats on time. There was also a problem in communication with individuals.

It is obvious that the current designed application will provide innovation to work health. When considering the seriousness of the financial and health effects of this issue, we think that the effect of our system will be significant, as it has been developed with the aim of guiding implementers in the process of revealing and reducing the WMSD risks.

\section{CONCLUSION}

In this study the related data were obtained from a pilot region. Supporting this study with research from multiple centers would have improved the effect of the study.

The application in our study includes office workers. On the other hand, this type of telerehabilitation applications may be widely used in rehabilitation science.

\section{Congresses}

The study has been presented at the '7th National Congress of Physiotherapy and Rehabilitation' between April 18-20, 2019.

Financial disclosures: This research was supported by the Scientific Research Projects Unit of Inonu University with the project number TSA-2019-1672.

Conflict of Interest: The authors declare that they have no competing interest.
Ethical approval: The permissions and consents required for the study were obtained from the Inonu University Health Sciences Non-Interventional Clinical Research Ethics Committee (Approval number $=2019 / 5-28$ ).

\section{REFERENCES}

1. Ozcan E, Esmaeilzadeh S, Basat H. Upper extremity workrelated musculoskeletal disorders among computer users and effectiveness of ergonomic interventions. Turk J Phys Med Rehabil 2011;57:236-41.

2. Hagberg $M$, Vilhemsson $R$, Tornqvist $E W$ et al. Incidence of self-reported reduced productivity owing to musculoskeletal symptoms: Associations with work place and individual factors among computer users. J Ergonomics 2007; 50:1820-34.

3. Tekeoğlu A, Yeldan I, Kuru T, et al. Assessment results for neck and back pain in workers with computer. Cerrahpaşa $\mathrm{J}$ Med 2018; 42::75-9.

4. Gerr F, Marcus M, Monteilh C. Epidemiology of musculoskeletal disorders among computer users: lesson learned from the role of posture and keyboard use. J Electromyogr and Kinesiol 2004;14:25-31.

5. Gordon CC, Bradtmiller B. Anthropometric change: Implications for office ergonomics. Work 2012;41:4606-11.

6. Blatter BM, Bongers PM. Duration of computer use and mouse use in relation to musculoskeletal disorders of neck or upper limb. Int J Indust Ergonom 2002;30(4-5):295-306.

7. Nnanna I, Chukwunonso N, Geoffrey 00, et al. Design of office furniture according to a human anthropometric data, school of engineering technology conference, 2016; At: Akanu Ibiam Federal Polytechnic Unwana, Ebonyi State, Nigeria.

8. Liu K, Zhang L, Zhu C, et al. An analysis of influence factors of sports bra comfort evaluation based on different sizes. J Textile Inst 2019;110:1792-9.

9. Rativa D, Fernandes BJ, Roque A. Height and weight estimation from anthropometric measurements using machine learning regressions. IEEE J Trans Eng Health med 2018;6:1-9. 
10. Amick BC, Robertson MM, De Rango K, et al. Effect of office ergonomics intervention on reducing musculoskeletal symptoms. Spine 2003;28:2706-11.

11. Mohammadipour F, Pourranjbar M, Naderi S, Forouzan Rafie F. Work-related Musculoskeletal Disorders in Iranian Office Workers: Prevalence and Risk Factors. J Med Life 2018;11:328-33.

12. Onishi T, Kurimoto $\mathrm{S}$, Suzuki $\mathrm{M}$, et al. Work-Related Musculoskeletal Disorders in The Upper Extremity Among the Staff of a Japanese University Hospital. Int Arch Occup Environ Health 2014;87:547-55.

13. Yılmaz F, Sahin F, Kuran B. Work related musculoskeletal disorders and therapy Nobel Medicus 2006;2:15-22.

14. Takala EP. Ergonomic interventions and prevention-a need for better understanding of implementation. Scand J Work Environ Health 2018;44:111- 2.

15. Cancelliere C, Cassidy JD, Ammendolia C, et al. Are workplace health promotion programs effective at improving presenteeism in workers? A systematic review and best evidence synthesis of the literature. BMC Public Health 2011;11:395.
16. Lee J, Lee M, Lim T, et al. Effectiveness of an applicationbased neck exercise as a pain management tool for office workers with chronic neck pain and functional disability: a pilot randomized trial. Eur J Integr Med 2017;12:87-92.

17. Ryu H, Jung J, Moon J. Health promotion program for office workers with SEM based on the WHO's healthy workplace framework. Health Prom Int 2020;36:1369-82.

18. Acık E, Kayıhan H, Aran OT. Investigation of anthropometric suitability of school furniture in primary schools-a pilot study. J Occup Therapy Rehab 2014;2:131-40.

19. Panagiotopoulou G, Christoulas K, Papanckolaou A, et al. Classroom furniture dimensions and anthropometric measures in primary school. Appl Ergon 2004;35:121-8.

20. Huang GB, Zhu QY, Siew CK. Extreme learning machine: theory and applications. Neurocomputing 2006;70:489501. 